\title{
Yield Loss Assessment and Management of Violet Wood Sorrel Weed on Maize
}

\author{
Govind $\mathrm{KC}$ \\ Ginger Research Programme, Kapurkot, Salyan \\ Current Address: National Maize Research Programme, Rampur, Chitawan
}

\begin{abstract}
A field experiment was conducted during rainy season of 2003 and 2004 in farmers' field of Dang district (650 masl) to assess the yield loss caused by violet wood sorrel (Oxalis corymbosa Dc) for maize (Zea mays) and to work out effective measure to control this weed. Violet wood sorrel (Chari Amilo) infestation was observed in maize, ginger, and Toria fields of Dang and Salyan districts as well as various mid hilly areas of Nepal. The weed once introduced in uplands, spreads in large scale within few years. Six treatments, comprising 2,4-D Na salt $2 \mathrm{~kg} / \mathrm{ha}$, Glyphosate 2 1/ha, Soil digging, turning and expose to sun two months prior to maize sowing were compared with weed free, weed free except Oxalis and weedy check plots. The presence of violet wood sorrel (VWS) in maize field ranging from 38 to 352.3 per square meter in 2003 and 18.6 to 195.5 per square meter in 2004 one month after intercultural operation does not cause significant effect on maize grain yield, 4297 to $4694 \mathrm{~kg} / \mathrm{ha}$ in 2003 and 3751.4 to $4473.6 \mathrm{~kg} / \mathrm{ha}$ in 2004 respectively. Thus significant loss in maize grain yield was not found due to higher VWS weed population $\left(352.3\right.$ and $\left.195.5 / \mathrm{m}^{2}\right)$ resulted in weedy check treatment and lower weed population $\left(38\right.$ and $\left.18.6 / \mathrm{m}^{2}\right)$ in herbicide applied treatment. Repeated application of herbicides at 17 and 37 days after maize sowing (DAMS) both 2,4-D and Glyphosate reduced the weed population in maize field but could not eradicate as it appears in next year but the population was significantly low $\left(59.5\right.$ and $\left.65.3 / \mathrm{m}^{2}\right)$ in herbicide applied plots compared to weedy check plot $\left(322.6 / \mathrm{m}^{2}\right)$ at 26 DAMS. It was revealed that presence of violet wood sorrel weed in maize field does not affect the grain yield in farmer's practice of weeding i.e. intercultural operation at 20 to 30 DAMS.
\end{abstract}

Key words: Chari Amilo, herbicide, Oxalis, violet wood sorrel, Zea mays

\section{INTRODUCTION}

Maize, the second important cereal, is the major staple food crop of the hilly regions in Nepal. Maize occupies 849,892 ha of land in Nepal with the productivity of $2.019 \mathrm{mt} / \mathrm{ha}$ (MoAC 2005). The national yield level of maize has been found lower as compared to its potentiality (Rampur Composite, $4.4 \mathrm{t} / \mathrm{ha}$ ). Despite of various high yielding varieties of maize available, poor adoption of integrated production technology by farmers has been existing situation, which might be responsible for lower productivity of maize in Nepalese context. There is ample opportunity to increase the production and productivity of maize in the country.

Maize is most sensitive to weed competition during its early growth period of 2-6 weeks after sowing due to profuse weed germination and rapid growth of weeds resulted by wider row spacing of maize. 
The loss caused by weed in maize ranges 40-70\% (Mandal 2000) and yield loss depend on type of weed flora and its severity. At ARS Pakhribas (eastern mid hill of Nepal) experimental result showed weedy environment resulted yield reduction up to $70 \%$ in maize (Mishra 2004). Maize Toria + Lentil is the major cropping system in upland in Dang. The farmers of different area in Dang reported the violet wood sorrel (Oxalis corymbosa Dc) weed problem in maize based cropping system since two decades ago. That noxious weed is perennial in nature and locally called Chari Amilo. This weed and its related species O. europea, O. latifolia and O.corniculata comes under oxaladaceae family infest different upland crops like maize, ginger, turmeric, toria, lentil etc. Infestation of this weed was observed in different up land crops in mid hills of eastern, western and mid western Nepal. But, survey and statistics for such particular weed is not available at present context. The weed once introduced in field, it spreads and cover whole field within 3-4 years due to its nature of spreading through bulb and bulbils as one bulb contains 70 to 120 bulbils (Rao 2000). All the crops in rainfed upland have been found infested and infestation takes place in early stage of crops as it germinated in June-July and Oct-Nov when it receives adequate moisture in soil. Farmers reported that fodder grass to livestock from maize field was decreased due to this weed and the effect of this weed was found negative on lentil crop amongst Toria + lentil mixed cropping system. This weed causes uneasy to field work too. Rao (2000) reported that this weed can be eradicate with repeated spray of Paraquat, Glyphosate is very effective and 2,4 D is partially effective. Loss assessment of this weed has not been found studied yet. The objective of the study was to assess the grain yield loss caused by violet wood sorrel on maize crop. This also aims to find out effective measure to control this weed in maize field under up land Bari condition.

\section{MATERIALS AND METHODS}

The experiment was carried out during rainy season of 2003 and 2004 at farmer's field of Dang valley (650 masl). The violet wood sorrel (VWS) infested field was selected for experimentation that was acidic in nature $(\mathrm{pH}$ 5.0). The experiment was laid out in randomized complete block design with 3 replications and plot size was $11.25 \mathrm{~m}^{2}$. Six treatments were selected for the present study (Table 1) and treatments were post-emergence application of Glyphosate and 2,4-D Na salt, soil digging followed by turning and exposed to sun 2 months prior to maize sowing, weed free up to 45 DAMS, weed free except Violet wood sorrel and weedy check in both years. Crop was fertilized with 80:40:40 kg/ha N: $\mathrm{P}_{2} \mathrm{O}_{5}: \mathrm{K}_{2} \mathrm{O}$ through DAP, Urea and Murate of Potash. Half of the N was top dressed at knee-high stage. Manakamana-1 was sown in rows $75 \mathrm{~cm}$ apart and $25 \mathrm{~cm}$ plant spacing. Planting was done in last week of May in 2003. Herbicides were applied at 17 days of maize sowing to those plots, which were with herbicides treatments and intercultural operation was done on $4^{\text {th }}$ day of spraying to all plots as per farmers' practice. Herbicides were reapplied at 37 and 45 days after sowing. Directed spray was done in inter row space of maize using plastic hood fitted at the nozzle of the sprayer. Soil digging followed by turning and exposed to sun two months before sowing was performed for soil turning treatment and for weed free up to 45 DAMS weeding of all weeds was done at 17, 37 and 45 DAMS while violet wood sorrel was not weeded and other weeds were weeded for weed free except Oxalis treatment. Intercultural operation was done for all treatments on $4^{\text {th }}$ day of herbicide application as per local practice. Plant population of VWS at 55 DAMS was observed for each treatment and effect in yield loss and variation was considered due to weed population difference.

In 2004 season, experiment was conducted in same field and plots with standard package of practices. Maize was sown in first week of May. One superimposed treatment, application of Agricultural lime $2 \mathrm{t} / \mathrm{ha}$ was included in second year of study. Lime was applied during maize sowing because it could not applied earlier due to moisture unavailability in soil. First weed count was done at 26 DAMS and herbicide application was done at 26 and 45 DAMS as per treatments. Second observation on weed population was made after intercultural operation and re-germination of weeds at 65 DAMS. 


\section{RESULTS AND DISCUSSION}

In 2003, post emergence application of Glyphosate $21 /$ ha reduced the violet wood sorrel (VWS) weed infestation with weed control efficiency over check plot $89.2 \%$ followed by 2 , 4 D Na salt 2 $\mathrm{kg} / \mathrm{ha}$ application (82.2\%). VWS weed population at 55 DAMS was $192.3 / \mathrm{m} 2$ in that plot which was treated as soil digging, turning and exposed to sun while VWS weed population was found 62.5 and 38.0 per square meter in 2,4 D and Glyphosate applied plot respectively. Presence of VWS population was very high $\left(352.3 / \mathrm{m}^{2}\right.$ at 55 DAMS $)$ in weedy check plot. Being a perennial weed and propagated through bulb and bulbils this weed germinated repeatedly. Other weed flora found infesting the experimental field was dominated by VWS. However, Ageratum conyzoids, Digitaria spp. were present in small number. All the VWS weeds in experimental field were killed and found in process of decomposing during 67 DAMS.

Effect of different treatments included in study was found non significant for maize grain yield variation in 2003 (Table 2). Oxalis weed infestation ranging from 38 to 352.2 per square meter was recorded in various treatments and there was no significant decrease in grain yield $(4332 \mathrm{~kg} / \mathrm{ha}) \mathrm{due}$ to higher VWS weed present $\left(352.3 / \mathrm{m}^{2}\right.$ at 55 DAMS) in weedy check plot compared to VWS infestation $\left(38 / \mathrm{m}^{2}\right.$ at 55 DAMS) in Glyphosate $21 / \mathrm{ha}$ applied treatment which yielded $4468 \mathrm{~kg} / \mathrm{ha}$ maize grain. Post emergence application of both herbicides does not affect the maize plants as all the treatments gave similar result of barren plants in percentage (6.3 to 8.3).

In 2004, after maize sowing, drought was occurred and maize growth was affected and slowed as well as weed was also affected and germinated late. First weed count and herbicide application were accomplished in 26 DAMS and after hoeing Oxalis population was observed at 65 DAMS. Like in first year, other weeds in the field were dominated by Oxalis. At 26 DAMS, weed population was significantly lower $\left(59.3\right.$ and $\left.65.3 / \mathrm{m}^{2}\right)$ in herbicide-applied plots in previous year compared to weed free except Oxalis and weedy check $\left(307.1\right.$ and $\left.322.6 / \mathrm{m}^{2}\right)$. This revealed that VWS infestation could be controlled by application of 2,4-D or Glyphosate. However, it could not be eradicate. Again oxalis weed population was significantly decreased (81.6 to $88.2 \%$ ) over check in herbicide-applied plots compared to weedy check at 65 DAMS (Table 1). Soil digging, turning prior to sowing $\left(130.6 / \mathrm{m}^{2}\right)$ and lime application $\left(195.5 / \mathrm{m}^{2}\right)$ were significantly inefficient to control VWS weed population compared to herbicide application $\left(18.6\right.$ and $\left.29.8 / \mathrm{m}^{2}\right)$ at 65 DAMS.

Table 1. Effect of herbicides and weeding on violet wood sorrel (Oxalis corymbosa) weed population (pop.) in maize field, 2003-2004

\begin{tabular}{|c|c|c|c|c|c|c|}
\hline \multirow{2}{*}{$\begin{array}{l}\mathrm{S} \\
\mathrm{N}\end{array}$} & \multirow[t]{2}{*}{ Treatment } & \multicolumn{3}{|c|}{ Oxalis Pop. $/ \mathrm{m}^{2}, 2003$} & \multicolumn{2}{|c|}{ Oxalis Pop. $/ \mathrm{m}^{2}, 2004$} \\
\hline & & 55 DAMS & $\begin{array}{r}\text { Decrease over } \\
\text { check, } \%\end{array}$ & 26 DA MS & 65 DA MS & $\begin{array}{r}\text { Decrease over } \\
\text { check, } \%\end{array}$ \\
\hline 1 & $\begin{array}{l}\text { Soil digging, turning and expose to sun } \\
60 / 30 \text { days before maize sowing }\end{array}$ & 192.3 & 45.3 & 184.4 & 130.6 & 17.4 \\
\hline 2 & 2, 4 D $80 \mathrm{WP} \mathrm{Na}$ salt $2 \mathrm{~kg} / \mathrm{ha}$ (Post Emer) & 62.5 & 82.2 & 59.5 & 18.6 & 88.2 \\
\hline 3 & Glyphosate $41 \%$ LS, 2 1/ha (Post Emer.) & 38.0 & 89.2 & 65.3 & 29.8 & 81.6 \\
\hline 4 & Weed free except Oxalis up to 45 DAMS & 191.3 & 45.4 & 307.1 & 122.6 & 22.5 \\
\hline 5 & Weed free up to 45 DAMS & 101.0 & 71.3 & 93.7 & 52.9 & 66.5 \\
\hline 6 & Weedy check (Farmer's practice) & 352.3 & - & 322.6 & 158.2 & - \\
\hline 7 & Agric. Lime, 2 t/ha & - & & 356.8 & 195.5 & -23.5 \\
\hline & $\mathrm{CV}, \%$ & 10.4 & & 16.6 & 11.0 & \\
\hline & LSD at 0.05 & 29.53 & & 58.7 & 19.8 & \\
\hline
\end{tabular}

Table 2. Maize grain yield as affected by different weed control regimes against violet wood sorrel weed, 2003-2004

\begin{tabular}{llrrrr}
\hline SN & Treatment & \multicolumn{3}{c}{ Maize, 2003 } & Maize, 2004 \\
\cline { 3 - 6 } & & $\begin{array}{r}\text { Grain yield, } \\
\mathrm{kg} / \mathrm{ha}\end{array}$ & $\begin{array}{r}\text { Barren } \\
\text { plants, \% }\end{array}$ & $\begin{array}{r}\text { Plant } \\
\text { pop/m } \mathrm{m}^{2}\end{array}$ & $\begin{array}{r}\text { Grain yield, } \\
\mathrm{kg} / \mathrm{ha}\end{array}$ \\
\hline 1 & Soil digging, turning and expose to sun 60/30 days & 4297 & 6.3 & 4.0 & 4054.2 \\
& before maize sowing & & & & \\
2 & 2, 4 D 80WP Na salt 2 kg/ha (Post Emergence) & 4457 & 7.3 & 3.55 & 4342.0 \\
3 & Glyphosate 41\% LS, 2 1/ha (Post Emergence.) & 4468 & 6.4 & 4.19 & 4473.6 \\
4 & Weed free except Oxalis up to 45 DAMS & 4694 & 6.8 & 3.93 & 3751.4 \\
5 & Weed free up to 45 DAMS & 4349 & 7.3 & 4.12 & 4208.4 \\
6 & Weedy check (Farmer's practice) & 4332 & 8.3 & 3.49 & 4001.7 \\
7 & Agric. Lime, 2 t/ha & & & 4.19 & 3984.6 \\
\hline & CV, \% & 8.1 & & 6.9 & 13.2 \\
& LSD at 0.05 & - & & 0.54 & - \\
\hline
\end{tabular}


In 2004, significant variation was found in maize plant population and therefore covariate analysis was performed for grain yield. All the treatments gave statistically comparable maize grain yield ranged from 3751.4 to $4473.6 \mathrm{~kg} / \mathrm{ha}$. However, highest adjusted grain yield $(4473.6 \mathrm{~kg} / \mathrm{ha})$ was obtained with Glyphosate 2 1/ha application followed by 2,4-D application (4342 kg/ha) and weed free up to 45 DAMS $(4208.4 \mathrm{~kg} / \mathrm{ha})$. Lowest grain yield $(4001.7 \mathrm{~kg} / \mathrm{ha})$ was obtained with weedy check treatment.

This experiment result showed that the weed had no significant effect on maize grain yield variation, though VWS weed population ranged significantly. From this, it was revealed that, presence of VWS in higher number $\left(352.3 / \mathrm{m}^{2}\right.$ and $\left.195.5 / \mathrm{m}^{2}\right)$ and lower number $\left(38.0 / \mathrm{m}^{2}\right.$ and $\left.18.6 / \mathrm{m}^{2}\right)$ resulted in comparable maize grain yield indicate that this VWS weed does not cause significant yield loss of maize grain under one intercultural operation practice at 20 to 30 DAMS.

\section{CONCLUSION}

Result of two year experiment indicate that the presence of weed Violet wood sorrel (Chari Amilo) in maize field ranging from 38 to 352.3 in 2003 and 18.6 to 195.5 per square meter in 2004 under one intercultural operation practice does not cause significant effect on maize grain yield (4297 to $4694 \mathrm{~kg} / \mathrm{ha}$ in 2003 and 3751.4 to 4473.6 in 2004) respectively. Repeated application of both herbicides Glyphosate 2 1/ha and 2,4 -D $2 \mathrm{~kg} / \mathrm{ha}$ reduced the VWS weed population in maize field and for its eradication more repeated application of herbicides has been required. Further study of yield loss assessment on other upland crops like toria, lentil, potato, ginger etc. caused by VWS (Oxalis corymbosa) will be helpful to know its harmful effect.

\section{ACKNOWLEDGEMENT}

The author is grateful to the NARC/NMRP/HMRP/CIMMYT for approving the Small Grant Project (SGP) and providing financial and technical support. Technical advice and suggestion of Dr JD Ranjit at Agronomy Division Khumaltar is highly appreciated. A special thank goes to CM Bhattarai and Durga Bahadur KC of GRP, Salyan for their field works to conduct the research activity.

\section{REFERENCES}

Mandal RC. 2000. Weed, weedicides and weed control. Principle and practice. Agrobios, India

Mishra M. 2004. Studies on weeds management in maize crop in the eastern hills of Nepal. In: Proceeding of the $24^{\text {th }}$ National Summer Crops Research Workshop, 2004. NARC. Pp. 180-181.

MoAC. 2005. Statistical information on Nepalese agriculture 2004/05. Agri-Business Promotion and Statistics Division, Ministry of Agriculture and Cooperatives, Singha Durbar, Kathmandu, Nepal.

Rao VS. 2000. Principles of weed science. Second Edition. Oxford and IBH Publishing Co. Pvt. Ltd. New Delhi. 